\title{
Purification and biochemical characterization of a cellulase from the digestive organs of the short-spined sea urchin Strongylocentrotus intermedius
}

\author{
Syuto Hasegawa - Kazuhiro Ura - Hiroyuki Tanaka • \\ Takao Ojima · Yasuaki Takagi
}

Received: 23 September 2011/ Accepted: 5 June 2012/Published online: 3 July 2012

(C) The Author(s) 2012. This article is published with open access at Springerlink.com

\begin{abstract}
We isolated a cellulase from the digestive organs of the short-spined sea urchin Strogylocentrotus intermedius using a combination of ion-exchange chromatography and gel filtration together with an assay for carboxymethylcellulase activity. The isolated cellulase was stained as a single band by Congo red. The molecular weight of the isolated cellulase, as determined by sodium dodecyl sulfate-polyacrylamide gel electrophoresis under reducing conditions, was $59 \mathrm{kDa}$. The isolated cellulase exhibited hydrolytic activity toward carboxymethyl cellulose, with an optimum temperature and $\mathrm{pH}$ of $30^{\circ} \mathrm{C}$ and $\mathrm{pH}$ 8.0, respectively. The thermal stability of the enzyme was characterized by determining the temperature at which activity decreased by $50 \%$ with treatment for $30 \mathrm{~min}$ at $\mathrm{pH}$ 7.0 and found to be $32{ }^{\circ} \mathrm{C}$. Cellulase activity remained at a high level at $5-20{ }^{\circ} \mathrm{C}$, which is the growth temperature of the short-spined sea urchin. These results confirm that the short-spined sea urchin should preferably be reared at a water temperature of $<20{ }^{\circ} \mathrm{C}$.
\end{abstract}

Keywords Cellulase $\cdot$ Digestive organ - Enzymatic properties · Protein isolation - Sea urchin

\footnotetext{
S. Hasegawa $\cdot$ Y. Takagi

Laboratory of Comparative Physiology,

Graduate School of Fisheries Science, Hokkaido University,

3-1-1 Minato-cho, Hakodate 041-8611, Japan

K. Ura $(\bowtie)$

Graduate School of Fisheries Science, Hokkaido University,

3-1-1 Minato-cho, Hakodate 041-8611, Japan

e-mail: kazu@fish.hokudai.ac.jp

H. Tanaka · T. Ojima

Laboratory of Marine Molecular Biology,

Graduate School of Fisheries Science, Hokkaido University,

3-1-1 Minato-cho, Hakodate 041-8611, Japan
}

\section{Introduction}

Cellulose, a major cell-wall component in plants, is a linear polysaccharide consisting of $\beta$-1,4-linked D-glucose residues that hydrolyzes the $\beta$-1,4-glycosyl linkages of the cellulose chain to produce cello-oligosaccharides, such as cellotriose and cellobiose [1]. This enzyme family is grouped into endolytic (endo-1,4- $\beta$-glucanase, EC 3.2.1.4) and exolytic (cellobiohydrolase, EC 3.2.1.91) enzymes. Complete depolymerization of cellulose to glucose requires another sort of cello-oligosaccharide-degrading enzyme, 1,4- $\beta$-glucosidase (EC 3.2.1.21). Thus far, cellulolytic enzymes have been isolated and characterized from bacteria [2], fungi [2], plants [3], molds [4], microbes [5], arthropods [6-11], nematodes [12], mollusks [13-19] and sea urchin [20].

The sea urchin is a well-known marine organism distributed widely from the rocky intertidal areas to the abyssal depths in all of the world's oceans. The gonads of sea urchins are a high value seafood product, and considerable research is being undertaken worldwide on the development of sea urchin aquaculture. More recently, considerable attention has been directed toward the development of artificial diets that enhance the quantity and quality of roe produced from sea urchin aquaculture [21, 22]. To develop such artificial diets and aquaculture systems, it is important to understand the digestive physiology of sea urchins. Although numerous edible sea urchins are kelp feeders, a surprisingly limited amount of information exists on the biochemical characterization of cellulases in the digestive system of sea urchins, although several reports have been published on the detection of cellulase activity in the digestive organs of sea urchins [13, 23-29]. In the respective studies, cellulase activity was analyzed using crude extracts from the digestive organs and, therefore, the exact 
biochemical characterization of the cellulase has remained unclear. Nishida et al. [20] reported the isolation, biochemical characterization and cDNA cloning of cellulase from the digestive organs of the Northern sea urchin Strongylocentrotus nudus. However, these authors focused on the biochemical characterization of the cellulase at a temperature that is not the considered to be the growth temperature of the Northern sea urchin. Thus, the isolation and biochemical characterization of digestive enzymes at the growth temperature of sea urchin is an important step toward understanding the digestive physiology of this organism and the development of efficient aquaculture systems. To the best of our knowledge, there has been not study on the biochemical characterization of cellulases from sea urchin at its growth temperature.

In the study reported here, we isolated and biochemically characterized a cellulase from the digestive organs of short-spined sea urchin, Strongylocentrotus intermedius. We also compared the biochemical characterization of the cellulases from the short-spined sea urchin and Northern sea urchin and discussed digestive physiology in terms of the biochemical characterizations of the cellulases at physiological growth temperatures.

\section{Materials and methods}

\section{Materials}

Digestive organs from the short-spined sea urchin were obtained at the local fish market in Hakodate, Hokkaido Prefecture, Japan. The pooled tissues $(1.5 \mathrm{~kg})$ were thoroughly rinsed in sea water to remove the intestinal contents and then dehydrated by the addition of 1.51 acetone at $-20{ }^{\circ} \mathrm{C}$. Precipitates were collected by centrifugation at $10,000 \mathrm{~g}$ for $15 \mathrm{~min}$, rinsed five times in $0.5 \mathrm{l}$ cold acetone, then rinsed again in 0.51 acetone at room temperature and finally collected by centrifugation at $10,000 \mathrm{~g}$ for $15 \mathrm{~min}$. The acetone-precipitated tissues were dried at room temperature, and the acetone-dried powder was stored at $-20{ }^{\circ} \mathrm{C}$ until use.

Purification of cellulase from the short-spined sea urchin

Crude enzyme was extracted from $2.5 \mathrm{~g}$ acetone-dried powder from the sea urchin digestive tracts with $100 \mathrm{ml}$ sodium phosphate $(10 \mathrm{mM}$; $\mathrm{pH} 7.0)$ at $0{ }^{\circ} \mathrm{C}$ for $30 \mathrm{~min}$ with occasional stirring. The enzyme extract was centrifuged at $10,000 \mathrm{~g}$ for $15 \mathrm{~min}$ and the supernatant then dialyzed against $10 \mathrm{mM}$ sodium phosphate $\left(\mathrm{pH} \mathrm{7.0)}\right.$ at $4{ }^{\circ} \mathrm{C}$ for $24 \mathrm{~h}$. The supernatant was then applied to a TOYOPEARLDEAE 650M column $(2.0 \times 26 \mathrm{~cm})$ (Toyo Soda Mfg Co.,
Tokyo, Japan). After unadsorbed materials were washed out with $10 \mathrm{mM}$ sodium phosphate $(\mathrm{pH} 7.0)$, proteins were eluted by a linear $\mathrm{NaCl}$ gradient from 0 to $300 \mathrm{mM}$ (total volume $700 \mathrm{ml})$ in $10 \mathrm{mM}$ sodium phosphate $(\mathrm{pH} 7.0)$ at a $90 \mathrm{ml} / \mathrm{h}$ flow rate. The eluate was collected in 8-ml fractions and carboxymethyl cellulose (CMCase) activity was determined. CMCase activity was detected in the fractions eluted at approximately $0.2 \mathrm{M} \mathrm{NaCl}$ (pooled as the DE-1 fraction). The DE-1 fraction was subjected to the same chromatography procedure after dialysis in $10 \mathrm{mM}$ sodium phosphate ( $\mathrm{pH}$ 7.0). The active fractions (pooled as the DE-2 fraction) were concentrated to $1.2 \mathrm{ml}$ with a Vivaspin $20 \mathrm{ml}$ centrifugal concentrator (Sartorius, Goettingen, Germany). The DE-2 fraction was subjected to ion exchange chromatography using a Mono Q 5/50 GL column (GE Healthcare $\mathrm{UK}$, Buckinghamshire, UK) after dialysis in $10 \mathrm{mM}$ sodium phosphate ( $\mathrm{pH}$ 7.0). The retained proteins were eluted with a linear $\mathrm{NaCl}$ gradient from 0 to $300 \mathrm{mM}$ at a $60 \mathrm{ml} / \mathrm{h}$ flow rate using a fast protein liquid chromatography system (GE Healthcare Biosciences). The active fractions were concentrated to $1.0 \mathrm{ml}$ with a Vivaspin $5 \mathrm{ml}$ centrifugal concentrator (Sartorius) and then subjected to gel filtration chromatography using a Superdex 75 column (GE Healthcare Biosciences) at a $60 \mathrm{ml} / \mathrm{h}$ flow rate. A 59-kDa protein with high CMCase activity was eluted as a single major peak.

Cellulase activity assay

A standard assay for cellulase activity was performed with a reaction mixture containing $0.52 \%$ carboxymethyl cellulose (CMC; medium viscosity, Bio Medics, Orange, CA) in $10-\mathrm{mM}$ sodium phosphate $(\mathrm{pH} 7.0)$ at $30{ }^{\circ} \mathrm{C}$. Reduced sugar produced by the reaction was determined using the method described by Park and Johnson [30]. One unit of cellulase is defined as the amount of enzyme that produces reduced sugar equivalent to $1 \mu \mathrm{mol}$ glucose during $1 \mathrm{~min}$. The temperature dependence of the cellulase was determined over a range of 5 to $60{ }^{\circ} \mathrm{C}$ and at $\mathrm{pH} 7.0 ; \mathrm{pH}$ dependence was determined at $30{ }^{\circ} \mathrm{C}$ in the following reaction buffers: $10 \mathrm{mM}$ HCl-glycine ( $\mathrm{pH} \quad 3-4), 10 \mathrm{mM} \quad \mathrm{CH}_{3} \mathrm{COOH}-$ $\mathrm{CH}_{3} \mathrm{COONa}(\mathrm{pH} 4-5), 10 \mathrm{mM} \mathrm{NaH} \mathrm{PO}_{4}-\mathrm{Na}_{2} \mathrm{HPO}_{4}(\mathrm{pH}$ 5-7), $10 \mathrm{mM}$ Tris- $\mathrm{HCl}$ (pH 7-9) and $10 \mathrm{mM} \mathrm{NaOH-gly-}$ cine ( $\mathrm{pH}$ 9-10). The thermal stability was characterized by incubating the isolated enzyme at different temperatures $\left(5-60{ }^{\circ} \mathrm{C}\right.$ ) and $\mathrm{pH} 7.0$ for $30 \mathrm{~min}$ followed by assaying the activity as described below.

Effects of metal ions on the cellulase activity

The effects of several metal ions and EDTA on the activity of the purified cellulase ( 1.5 units $/ \mathrm{ml})$ activity was determined in a reaction mixture containing $1 \mathrm{mM}$ (final 
concentration) of $\mathrm{AgNO}_{3}, \mathrm{CaCl}_{2}, \mathrm{CdCl}_{2}, \mathrm{CoCl}_{2}, \mathrm{CuSO}_{4}$, $\mathrm{FeCl}_{2}, \mathrm{MgCl}_{2}, \mathrm{MnCl}_{2}, \mathrm{ZnCl}_{2}$ and EDTA in $10 \mathrm{mM}$ sodium phosphate (pH 7.0) at $30{ }^{\circ} \mathrm{C}$ for $60 \mathrm{~min}$, followed by an assay of the activity as described below.

Sodium dodecyl sulfate-polyacrylamide gel electrophoresis

Sodium dodecyl sulfate-polyacrylamide gel electrophoresis (SDS-PAGE) was performed with $3 \%$ stacking and $10 \%$ separating gels as described by Laemmli et al. [31]. Samples were treated with equal volumes of sample buffer containing $4 \%$ SDS, $14 \%$ glycerol and $10 \%$ 2-mercaptoethanol at $100{ }^{\circ} \mathrm{C}$ for 2 min or equal volumes of sample buffer containing $4 \%$ SDS and $20 \%$ glycerol. Gels were stained with $0.1 \%$ Coomassie brilliant blue R-250 in ethanol, acetic acid and deionized water (DW) (40:10:50), then destained in ethanol, acetic acid, glycerol and DW (200:50:25:725). Molecular weights were estimated using Broad Range Standard Markers (New England Biolabs, Ipswich, MA).

Detection of cellulase activity in polyacrylamide gels

Cellulase activity in the polyacrylamide gels was detected using a modification of the method reported by Beguin [32]. Briefly, enzyme samples were treated with equal volumes of sample buffer containing $0.25 \%$ SDS and $10 \%$ glycerol. After SDS-PAGE, SDS was removed by washing the gel twice for $30 \mathrm{~min}$ in $10 \mathrm{mM}$ sodium phosphate $(\mathrm{pH} \mathrm{7.0)}$ and $25 \%$ isopropanol, followed by another two washes for $10 \mathrm{~min}$ in $10 \mathrm{mM}$ sodium phosphate (pH 7.5). Agar gels ( $2 \%$; thickness $5 \mathrm{~mm}$ ) containing $0.1 \% \mathrm{CMC}$ in $10 \mathrm{mM}$ Tris- $\mathrm{HCl}(\mathrm{pH} 7.5)$ were prepared. Excess liquid on the polyacrylamide gels was removed by wiping the gel surface, and the gels were then laid on top of the agar gels and incubated at $37{ }^{\circ} \mathrm{C}$ for $3 \mathrm{~h}$. After incubation, the agar gels were stained with $0.1 \%$ Congo red solution and then destained with $1 \mathrm{M} \mathrm{NaCl}$. All procedures were performed at $4{ }^{\circ} \mathrm{C}$ except for the incubation.

\section{Thin-layer chromatography}

Thin-layer chromatography (TLC) for analysis of degradation products of cellulose and cello-oligosaccharides was performed on a TLC-60 plate (Merck, Darmstadt, Germany) and a developing solvent consisting of $n$-butanol/acetic acid/ water $(2: 1: 1, \mathrm{v} / \mathrm{v} / \mathrm{v})$. The sugar developed on the plate was detected by heating at $120{ }^{\circ} \mathrm{C}$ for $15 \mathrm{~min}$ after being sprayed with $10 \%(\mathrm{v} / \mathrm{v})$ sulfuric acid ethanol. Cellulose powders were purchased from Advantec (San Diego, CA) and Merck. The $0.1-\mathrm{ml}$ reaction mixture $(0.5 \mathrm{mg}$ of phosphoric acidswollen cellulose and crystalline cellulose, $5 \mathrm{mM}$ sodium phosphate, $\mathrm{pH} 7.0,0.26 \mathrm{U}$ of purified cellulase) was incubated at $30{ }^{\circ} \mathrm{C}$ for up to $24 \mathrm{~h}$. The supernatant of the reaction mixture was subjected to TLC. The reaction mixture of the $0.05 \mathrm{ml}$ containing $0.05 \mathrm{mg}$ of $\mathrm{G} 2$ (cellobiose)-G6 (cellohexaose), $5 \mathrm{mM}$ sodium phosphate ( $\mathrm{pH} 7.0$ ), and $0.13 \mathrm{U}$ of purified cellulase was incubated at $30^{\circ} \mathrm{C}$ for $20 \mathrm{~h}$, then subjected to TLC.

\section{Protein concentration}

Protein concentrations were determined with bovine serum albumin fraction V (Wako Pure Chemicals, Osaka, Japan) as a standard protein using either the biuret method [33] or the method described elsewhere by Lowry et al. [34].

Amino acid sequencing

The N-terminal amino acid sequence of the intact protein was determined by electrophoretically blotting a sample onto a polyvinyldifluoridine membrane (Advantec) and performing the sequencing in an ABI 492HT protein sequencer (Applied Biosystems, Foster city, CA, USA) following the manufacturer's instructions.

\section{Results}

\section{Cellulase isolation}

A cellulase was isolated from the acetone-dried powder of the digestive organs of the short-spined sea urchin. Isolation was performed using a combination of ion-exchange chromatography and gel filtration together with an assay for CMCase activity (Fig. 1). The isolation procedures resulted in a target protein that was purified to a 1,156-fold concentration with a $5.4 \%$ final yield and $28.9 \mathrm{U} / \mathrm{mg}$ specific activity (Table 1). The purified short-spined sea urchin cellulase showed a single band with an apparent molecular weight of $59 \mathrm{kDa}$, as determined by SDS-PAGE under reducing conditions (Fig. 2a), and was stained by Congo red (Fig. 2b).

Enzymatic properties of short-spined sea urchin cellulase

The basic properties of short-spined sea urchin cellulase were investigated and compared with those of cellulase from the Northern sea urchin [20]. As shown in Fig. 3, the optimal temperature and $\mathrm{pH}$ of short-spined cellulase was $30{ }^{\circ} \mathrm{C}$ and $\mathrm{pH} 8.0$, respectively. These properties differ from those of the Northern sea urchin cellulase, which are $35{ }^{\circ} \mathrm{C}$ and $\mathrm{pH}$ 6.3, respectively (Fig. 3a, b). The thermal stability was characterized as the temperature at which 

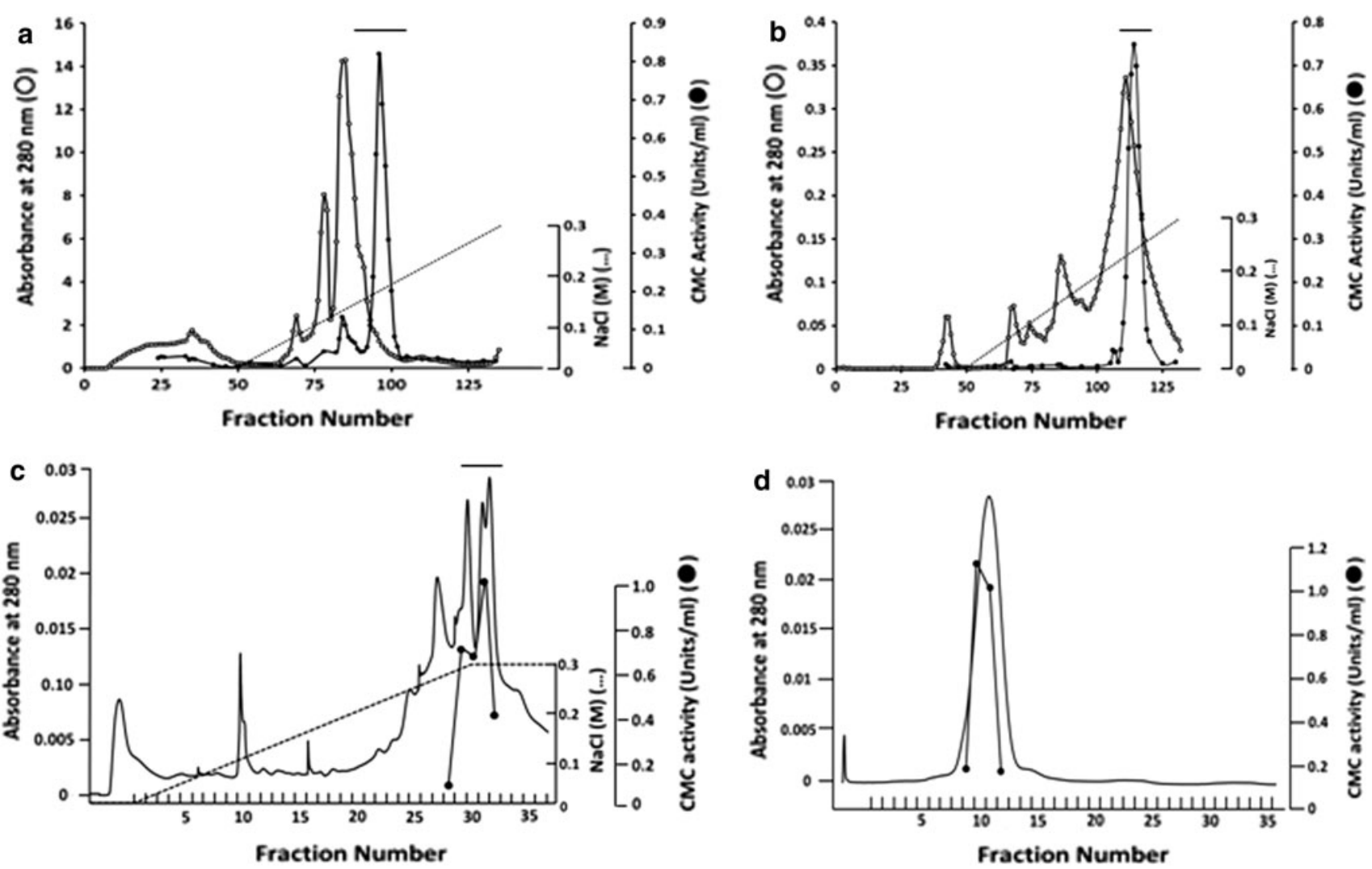

Fig. 1 Purification of short-spined sea urchin (Strogylocentrotus intermedius) cellulase. a First TOYOPEARL-DEAE 650M chromatography. b Second TOYOPEARL-DEAE 650M chromatography. c MonoQ column chromatography. d Superdex 75 gel filtration. The chromatography conditions are described in the Materials and methods. The fractions indicated by solid bars were pooled and

designated as the DE-1 fraction (a; fractions eluted at approximately $0.2 \mathrm{M} \mathrm{NaCl}$ ), DE-2 fraction (b; active fractions obtained after DE-1 fraction was subjected to the same chromatography procedure after dialysis in $10 \mathrm{mM}$ sodium phosphate), MonoQ fraction (c) and Superdex 75 fraction $(\mathbf{d})$

Table 1 Purification of cellulase from the short-spined sea urchin (Strongylocentrotus intermedius)

${ }^{a}$ The chromatography conditions are described in the Materials and methods

\begin{tabular}{lccccc}
\hline Purification step & a & $\begin{array}{l}\text { Total } \\
\text { protein }(\mathrm{mg})\end{array}$ & $\begin{array}{l}\text { Specific } \\
\text { activity }(\mathrm{U} / \mathrm{mg})\end{array}$ & $\begin{array}{l}\text { Total } \\
\text { activity }(\mathrm{U})\end{array}$ & \multicolumn{2}{l}{\begin{tabular}{l} 
Purification yield \\
\cline { 5 - 6 }
\end{tabular}} & & & & Fold & $\%$ \\
\hline Crude extract & $1,677.8$ & 0.025 & 42.12 & 1 & 100 \\
Fist DEAE fraction & 24.9 & 0.743 & 18.53 & 29.7 & 43.9 \\
Second DEAE fraction & 5.08 & 2.27 & 11.53 & 90.8 & 27.3 \\
Mono Q & 0.20 & 16.9 & 3.39 & 676 & 8.0 \\
Superdex 75 & 0.08 & 28.9 & 2.31 & 1,156 & 5.4 \\
\hline
\end{tabular}

activity decreased to $50 \%$ with treatment for $30 \mathrm{~min}$ at $\mathrm{pH}$ 7.0; this temperature was found to be 32 and $37^{\circ} \mathrm{C}$ for short-spined sea urchin and Northern sea urchin cellulase, respectively (Fig. 3c). Table 2 shows the effect of metal ions and EDTA on the activity of the short-spined sea urchin cellulase. The activity of cellulase was strongly inhibited by the addition of $\mathrm{Ag}^{+}$and $\mathrm{Cu}^{2+}$. The TLC analysis showed that short-spined sea urchin cellulase has a higher degradation activity toward phosphoric acid-swollen cellulose than toward crystalline cellulose (Fig. 4a, b). The short-spined sea urchin cellulase degraded the phosphoric acid-swollen cellulose to produce cellotetraose, cellotriose and cellobiose as major products (Fig. 4a). It also degraded the crystalline cellulose to produce cellotetraose, cellootriose and cellobiose; however, the degradation activity on this substrate was very low (Fig. 4b). Figure $4 c$ shows the degradation of the cello-oligosaccharides. The short-spined sea urchin cellulase readily degraded both cellohexaose and cellopentaose to cellotetraose, cellotriose, cellobiose and glucose, and slowly degraded cellotetrose to cellotriose, cellobiose and glucose. However, it scarcely degraded cellotriose and cellobiose. 




Fig. 2 a Sodium dodecyl sulfate-polyacrylamide gel electrophoresis (SDS-PAGE) of short-spined sea urchin cellulase from various purification steps. b Detection of cellulase activity in polyacrylamide gels. Gels were stained by Congo red. Crude Crude extract, $D E-1$ DE1 fraction, $D E-2$ DE-2 fraction, Mono $Q$ MonoQ fraction, Superdex 75 Superdex 75 fraction, $M W$ molecular-weight marker proteins

$\mathrm{N}$-terminal amino-acid sequence

Using a protein sequencer, we determined the 15 residue $\mathrm{N}$-terminal amino acid sequence of short-spined sea urchin cellulase to be SDYXDVLHKSILFFE. This sequence showed $86 \%$ identity with the Northern sea urchin cellulase sequence at amino acid positions 18-32 (Table 3).

\section{Discussion}

To date, cellulases have been isolated and characterized from various organisms. However, biochemical characterization of the cellulases in marine organisms has been limited. In sea squirts and sea urchins, cellulase primary structures have been analyzed by means of genomic and expressed sequence tag analyses [35, 36]. In more recent studies, cellulases have been isolated from abalone and sea urchin for biochemical characterization and primary structure determination $[18,20]$. In our study, short-spined sea urchin cellulase was purified using a combination of ionexchange chromatography and gel filtration together with CMCase activity assays. The molecular weights of cellulases have been reported from various organisms, such as plants (50-70 kDa [3]), molds (42 kDa [4]), arthropods (40-47 kDa [6, 10, 11]), nematodes (49 kDa [12]), rotifer (62 kDa [37]), mollusks (44-70 kDa [15-18]) and sea urchin (54 $\mathrm{kDa}[20])$, and the range has been found to be quite wide. The molecular weight of purified short-spined sea urchin cellulase was estimated to be $59 \mathrm{kDa}$, a value which falls well within the range of previously reported cellulases from marine invertebrates, including abalone [18] and Northern sea urchin [20]. Furthermore, the N-terminal amino-acid sequence of purified short-spined sea urchin cellulase showed $86 \%$ identity with that of Northern sea urchin [20], providing good proof that the purified protein is actually the cellulase of short-spined sea urchin.

In this study, we investigated the effects of metal ions and EDTA on the activity of short-spined sea urchin cellulase. To the best of our knowledge, this is the first such report in marine organisms. The activity of the enzyme was strongly inhibited with the addition of $\mathrm{Ag}^{+}$and $\mathrm{Cu}^{2+}$. To date, there are very few published studies on the effect of metal ions on the activity of cellulase. In Bacillus sphaericus, the activity of cellulase was inhibited by adding $\mathrm{Fe}^{3+}$ and $\mathrm{Hg}^{2+}$ and stimulated by adding $\mathrm{Co}^{2+}$ and $\mathrm{K}^{+}$[38]. Working with various Bacillus strains, Mawadza et al. [39] isolated and characterized two types of cellulases (HR66 and $\mathrm{CH} 43$ ). The activity of HR66 and $\mathrm{CH} 43$ was stimulated by adding $\mathrm{Co}^{2+}$ and inhibited by adding $\mathrm{Hg}^{2+}$. The activity of $\mathrm{CH} 43$ was also inhibited by adding $\mathrm{Ag}^{+}$, but that of HR66 was stimulated by adding $\mathrm{Ag}^{+}$. Other metal ions $\left(\mathrm{K}^{+}\right.$, $\left.\mathrm{Mg}^{2+}, \mathrm{Cu}^{2+}, \mathrm{Ca}^{2+}, \mathrm{Ni}^{2+}, \mathrm{Zn}^{2+}, \mathrm{Fe}^{3+}\right)$ had no effects on the activity of either HR66 or $\mathrm{CH} 43$. Based on their results, the authors suggested that the effects of metal ions on the activity of cellulase was different depending on the type of cellulase and organisms. We found that the short-spined sea urchin cellulase showed a higher degradation activity toward phosphoric acid-swollen cellulose than to crystalline cellulose. Moreover, the degradation pattern was similar to that of the Northern sea urchin [20]. The short-spined sea urchin cellulase scarcely degraded cellotriose and cellobiose. $\beta$-Glucosidase activity was reported to be present in crude extracts from digestive organs of the sea urchin [40, 41], leading to the suggestion that in the sea urchin cellulose is first degraded to cellotriose and cellobiose by the cellulase, followed by the possible degradation of these cellooligosaccharides to glucose by $\beta$-glucosidase. However, no data have been published on the isolation and biochemical characterization of $\beta$-glucosidase in sea urchin. In addition, in another study a cellulase was purified which raised a specific antibody against the enzyme from abalone; this antibody reacted with three protein bands by western blotting analysis, suggesting that there are several types of cellulase in marine organisms (Ojima, unpublished data). Further studies are being contemplated to determine the degradation mechanism of cellulose in sea urchin.

In echinoderms, less attention has been paid to the relationship between digestive enzymes and digestive physiology. Almost every study performed to date has 

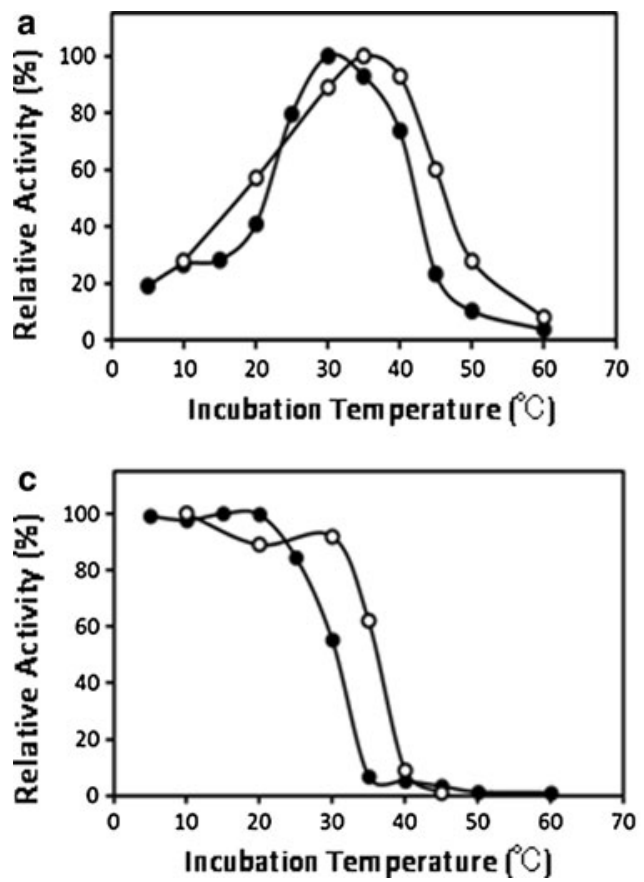

Fig. 3 Temperature, pH dependence and thermal stability activities of short-spined sea urchin and Northern sea urchin cellulases. a Activities of the cellulases were measured at various temperatures in a reaction mixture containing $0.52 \%$ carboxymethyl cellulose (CMC) and $10 \mathrm{mM}$ sodium phosphate $(\mathrm{pH} 7.0)$. b Activities were measured in the presence of $0.52 \% \mathrm{CMC}$ at $30{ }^{\circ} \mathrm{C}$ in various reaction buffers at varying $\mathrm{pH}$, including $10 \mathrm{mM} \mathrm{HCl}$-glycine ( $\mathrm{pH} 3-4)$ (filled triangles), $10 \mathrm{mM} \mathrm{CH}{ }_{3} \mathrm{COOH}-\mathrm{CH}_{3} \mathrm{COONa}(\mathrm{pH} 4-5)$ (solid lines),

Table 2 N-terminal amino acid sequence of the cellulases

\begin{tabular}{lc}
\hline Organisms & $\begin{array}{l}\text { N-terminal amino acid } \\
\text { sequence of the cellulase }\end{array}$ \\
\hline $\begin{array}{c}\text { Strongylocentrotus intermedius } \\
\text { (short-spined sea urchin) }\end{array}$ & SDYXDVLHKSILFFE \\
$\begin{array}{c}\text { Strogylocentrotus nudus } \\
\text { (Northern sea urchin) }\end{array}$ & YDYXDVIHKSILFFE \\
\hline
\end{tabular}

Table 3 Effects of metal ions and EDTA on the activity of cellulase of Strongylocentrotus intermedius

EDTA,

Ethylenediaminetetraacetic acid

\begin{tabular}{ll}
\hline Compound & $\begin{array}{l}\text { Relative } \\
\text { activity (\%) }\end{array}$ \\
\hline None & 100 \\
$\mathrm{AgNO}_{3}$ & 5.5 \\
$\mathrm{CaCl}_{2}$ & 97.0 \\
$\mathrm{CdCl}_{2}$ & 100.5 \\
$\mathrm{CoCl}_{2}$ & 95.2 \\
$\mathrm{CuSO}_{4}$ & 43.5 \\
$\mathrm{FeCl}_{2}$ & 83.6 \\
$\mathrm{MgCl}$ & 96.1 \\
$\mathrm{MnCl}$ & 106.7 \\
$\mathrm{ZnCl}$ & 101.7 \\
$\mathrm{EDTA}$ & 93.9 \\
\hline
\end{tabular}

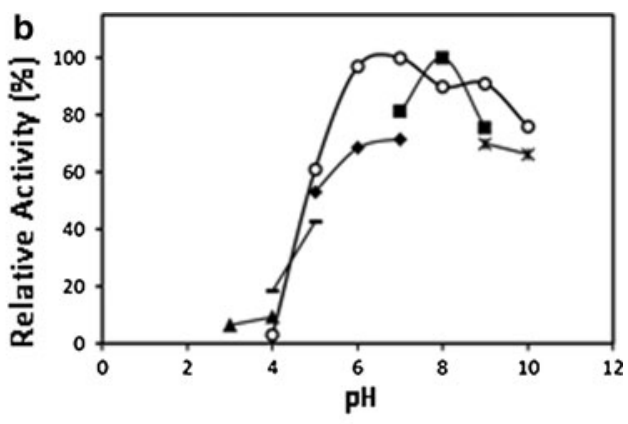

$10 \mathrm{mM} \mathrm{NaH} \mathrm{PO}_{4}-\mathrm{Na}_{2} \mathrm{HPO}_{4}$ (pH 5-7) (filled diamonds), $10 \mathrm{mM}$ Tris- $\mathrm{HCl}$ ( $\mathrm{pH}$ 7-9) (filled squares), $10 \mathrm{mM} \mathrm{NaOH}-$ glycine ( $\mathrm{pH} 9-10)$ ( $x$ symbols) . c Thermal stability of the purified enzyme was measured by pre-incubation at various temperatures at a constant $\mathrm{pH}$, and the activity was assayed in a reaction mixture containing $0.52 \% \mathrm{CMC}$, $10 \mathrm{mM}$ sodium phosphate ( $\mathrm{pH}$ 7.0). Filled circles Short-spined sea urchin cellulase; open circles Northern sea urchin cellulase (Nishida et al. [20])

focused on the biochemical characterization of digestive enzymes at temperatures not considered to be the growth temperature of sea urchin. Consequently, enzyme activity has been assayed at temperatures ranging from 25 to $35^{\circ} \mathrm{C}$ in various studies [28, 42-45], but few studies have focused on assaying digestive enzyme activity at the growth temperature of echinoderms. Klinger et al. [46] showed that there was no difference in digestive enzyme activity between polar and subtropical sea urchins at 15 and $25^{\circ} \mathrm{C}$ after sea urchins had been reared at 16 or $23{ }^{\circ} \mathrm{C}$. Thus far, there are several reports on the detection of cellulase activity in the digestive organs of sea urchin [13, 23-29], and the activity of digestive enzymes from sea urchins has been analyzed using crude extracts from the digestive organs. However, the physiological function of digestive enzymes in the digestive system of sea urchins remains unclear. The isolation and biochemical characterization of the digestive enzymes is an important step towards understanding the digestive physiology of the sea urchin. In echinoderms, the isolation and biochemical characterization of a cellulase from the digestive organs of Northern sea urchin was first reported by Nishida et al. [20]. However, this report also focused on the biochemical characterization of a cellulase. 
Fig. 4 Degradation of phosphoric acid-swollen cellulose, crystalline cellulose and cello-oligosaccharides by the short-spined sea urchin cellulase. The reaction mixture of $0.1 \mathrm{ml}$ containing $0.5 \mathrm{mg}$ of phosphoric acid-swollen cellulose (a) or crystalline cellulose (b), $5 \mathrm{mM}$ sodium phosphate $(\mathrm{pH} 7.0)$ and $0.26 \mathrm{U}$ of purified cellulase was incubated at $30^{\circ} \mathrm{C}$ for up to $24 \mathrm{~h}$. The supernatant of the reaction mixture was subjected to thin-layer chromatography (TLC). The reaction mixture of $0.05 \mathrm{ml}$ containing $0.05 \mathrm{mg}$ of $\mathrm{G} 2-\mathrm{G} 6,5 \mathrm{mM}$ sodium phosphate $(\mathrm{pH} 7.0)$ and $0.13 \mathrm{U}$ of purified cellulase was incubated at $30{ }^{\circ} \mathrm{C}$ for $20 \mathrm{~h}$, then subjected to TLC (c). G1 Glucose, $G 2$ cellobiose, $G 3$ cellotriose, $G 4$ cellotetraose, $G 5$ cellopentaose, $G 6$ cellohexaose, $M$ marker sugars

In our study, we isolated a cellulase from the digestive tract of the short-spined sea urchin and found that the optimum temperature (approximately $30^{\circ} \mathrm{C}$ ) for short-spined sea urchin cellulase activity was lower than that of Northern sea urchin cellulase (approximately $35^{\circ} \mathrm{C}$ ) [20]. Moreover, the enzyme activity remained at $20-40 \%$ between 5 and $20{ }^{\circ} \mathrm{C}$, which is the growth temperature for short-spined sea urchin. In our previous study, we isolated and biochemically characterized the proteolytic enzyme subtilase from the digestive tracts of the short-spined sea urchin, which is a major proteolytic enzyme in sea urchin, and determined that the optimum temperature is approximately $50{ }^{\circ} \mathrm{C}$ and that enzyme activity remains at $40-50 \%$ between 10 and $20{ }^{\circ} \mathrm{C}$ [47]. The thermal stability of the short-spined sea urchin cellulase was also characterized, and although the enzyme activity remained at a high level between 5 and $20^{\circ} \mathrm{C}$, it decreased abruptly above $20{ }^{\circ} \mathrm{C}$ and was $50 \%$ at $32{ }^{\circ} \mathrm{C}$. In contrast, in the Northern sea urchin, the enzyme activity remained at a high level between 10 and $30{ }^{\circ} \mathrm{C}$ and was $50 \%$ at $37{ }^{\circ} \mathrm{C}$. Gonadal growth and growth rate are significantly suppressed in the short-spined sea urchin when rearing occurs at a water temperature of $>21{ }^{\circ} \mathrm{C}$ versus $<20{ }^{\circ} \mathrm{C}$ [48]. Also, the value of assimilation efficiency in the short-spined sea urchin was found to be $55 \%$ at approximately $5{ }^{\circ} \mathrm{C}$ after kelp Laminaria japonica was supplied as food [49, 50]. In addition, gonadal weight in the short-spined sea urchin increased at approximately $5{ }^{\circ} \mathrm{C}$ after the kelp L. japonica had been supplied as food (T. Kayaba, personal communication), but it did not change in the Northern sea urchin under the same feeding conditions (K. Ura, unpublished data). In $S$. droebachiens and Tripneustes esculentus, both residents of low-temperature water zones, the value of assimilation efficiency is $50-60 \%$ in winter $[51,52]$. Other sea urchins (S. droebachiens) which live in water zones characterized by the same low temperature as the habitat of the short-spined sea urchin are known to undergo a decrease in survival rate at water temperatures of $>19^{\circ} \mathrm{C}$, with the lethal temperature being approximately $24{ }^{\circ} \mathrm{C}$ [53]. In comparison, in the Northern sea urchin, which can live at higher water temperatures than the short-spined sea urchin, the value of assimilation efficiency is approximately $50 \%$ at $10-25{ }^{\circ} \mathrm{C}$;
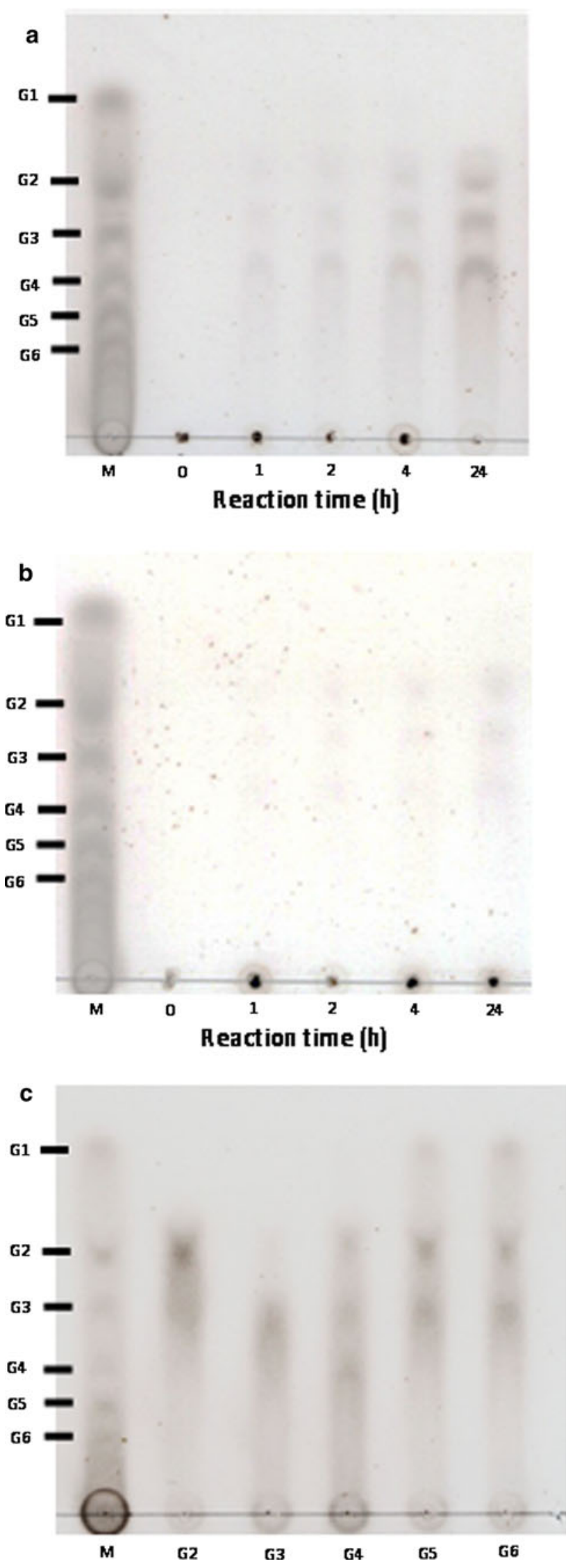
however, assimilation efficiency is approximately $10 \%$ at $5{ }^{\circ} \mathrm{C}$ after kelp is supplied as food [54]. From these results, we conclude that the activity of the short-spined sea urchin cellulose is weaker at high water temperatures than the Northern sea urchin cellulose.

The $\mathrm{pH}$ of the food canal of the sea urchin in an unfed state food is around pH 7.0 [55]. In the short-spined sea urchin, the optimal $\mathrm{pH}$ of purified cellulase was found to be $\mathrm{pH} 8.0$; in contrast, that of the Northern sea urchin is $\mathrm{pH}$ 7.0, although enzyme activity was high at around $\mathrm{pH}$ 6.0-9.0. In our previous study, we isolated and biochemically characterized the proteolytic enzyme subtilase from the digestive tracts of the short-spined sea urchin and found that the optimum $\mathrm{pH}$ for subtilase activity is approximately $\mathrm{pH}$ 9.0. These data suggest that the digestive enzymes of sea urchin function under weak alkaline conditions. However, to date there have been no published studies on the changes in the $\mathrm{pH}$ of the food canal of sea urchin after feeding. Further work is needed to determine the physiological conditions of the food canal and the role of each of the enzymes in the food canal of sea urchin.

In Northern sea urchin, although cellulase activity has been detected in the esophagus, stomach, and intestine (T. Ojima, unpublished data), the localization of the cellulase in the digestive organs is still unclear. In our previous study, we isolated subtilase and raised a specific antibody against the enzyme [47]. Moreover, we found that subtilase is localized in granules in the anterior and posterior stomach and the anterior intestine [56]. From these data, it is likely that the localization of subtilase and cellulase may differ. Further work is needed to determine the localization of cellulase in the digestive organs of sea urchin.

In conclusion, we isolated and biochemically characterized a cellulase from the digestive organs of the shortspined sea urchin. We demonstrated that cellulase from the short-spined sea urchin possesses a physiological function at low temperatures, which is the growth temperature of this organism. Further work is in progress to confirm the localization of cellulase in the digestive organs in order to gain an understanding of the digestive system of sea urchin.

Acknowledgments This study was supported by a Grant-in-Aid for Scientific Research from the Ministry of Education, Science and Culture, Japan.

Open Access This article is distributed under the terms of the Creative Commons Attribution License which permits any use, distribution, and reproduction in any medium, provided the original author(s) and the source are credited.

\section{References}

1. Bhat MK, Bhat S (1997) Cellulose degrading enzymes and their potential industrial applications. Biotech Adv 15:583-620
2. Tomme P, Warren RAJ, Gilkes NR (1995) Cellulose hydrolysis by bacteria and fungi. Adv Microbiol Physiol 37:1-81

3. Brummel DA, Lashbrook CC, Bennett AB (1994) Plant endo-1,4$\beta$-D-glucanase. ACS Symp Ser 566:100-129

4. Blume JE, Ennis HL (1991) A Dictyostelium discoideum cellulase is a member of a spore germination-specific gene family. J Biol Chem 266:15432-15437

5. Moriya S, Ohkuma M, Kudo T (1998) Phylogenetic position of symbiotic protest Dinemympha exlis in the hindgut of the termite Reticulitermes speratus inferred from the protein phylogeny of elongation factor $1 \alpha$. Gene 210:221-227

6. Watanabe H, Nakamura M, Tokuda G, Yamaoka I, Scrivener AM, Noda H (1997) Site of secretion and properties of endogenous endo- $\beta$-1,4-glucanase components from Reticuliterms speratus (Kolbe), a Japanese subterranean termite. Insect Biochem Mol Biol 27:305-313

7. Watanabe H, Noda H, Tokuda G, Lo N (1998) A cellulase gene of termite origin. Nature 394:330-331

8. Tokuda G, Watanabe H, Matsumoto T, Noda H (1997) Cellulose digestion in the wood-eating higher termite, Nasutitermes takasagonesis (Shiraki): distribution of cellulases and properties of endo- $\beta$-1,4-glucanase. Zool Sci 14:83-93

9. Tokuda G, Lo N, Watanabe M, Slaytor M, Matsumoto T, Noda H (1999) Metazoan cellulase genes from termites: intron/exon structure and sites of expression. Biochem Biophys Acta 1447:146-159

10. Xue XM, Anderson AJ, Richardson NA, Anderson AJ, Xue GP, Mather PB (1999) Characterization of cellulase activity in the digestive system of the redclaw cray-fish (Cherax quadricarinatus). Aquaculture 180:373-386

11. Sugimura M, Watanabe H, Lo N, Saito H (2003) Purification characterization, cDNA cloning and nucleotide sequence of a cellulase from the yellow-spotted longicorn beetle, Psacothea hilaris. Eur J Biochem 270:3455-3460

12. Smant G, Stokkermans JPWG, Yan Y, De Boer JM, Baum TJ, Wang X, Hussey RS, Gommers FJ, Henrissat B, Davis EL, Helder J, Schots A, Bakker J (1998) Endogenous cellulases in animals: isolation of $\beta-1,4-e n d o g l u c a n a s e s$ genes from two species of plant-parasitic cyst nematodes. Proc Natl Acad Sci USA 95:4906-4911

13. Yokoe Y, Yasumasu I (1964) The distribution of cellulase in invertebrates. Comp Biochem Physiol 13:323-338

14. Marshall JJ (1973) Purification of $\beta$-1,4-glucan hydrolase (cellulase) from the snail, Helix pomatia. Comp Biochem Physiol 44B:981-988

15. Marshall JJ, Grand RJA (1976) Characterization of a $\beta$-1,4-glucan hydrolase from the snail, Helix pomatia. Comp Biochem Physiol 53B:231-237

16. Anzai H, Nisizawa K, Matsuda K (1984) Purification and characterization of a cellulase from Dolabella auricularia. J Biochem 96:1381-1390

17. Xu B, Hellman U, Ersson B, Jason J-C (2000) Purification, characterization and amino-acid sequence analysis of a thermostable, low molecular mass endo- $\beta$-1,4-glucanase from blue mussel, Mytilus edulis. Eur J Biochem 267:4970-4977

18. Suzuki K, Ojima T, Nishita K (2003) Purification and cDNA cloning of a cellulase from abalone Haliotis discus hannai. Eur $\mathrm{J}$ Biochem 270:771-778

19. Wang J, Ding M, Li Y, Chen Q, Xu G, Zhao F (2003) Isolation of a multifunctional enzogeneous cellulase gene from mollusk, Ampullaria crossean. Acta Biochem Biophys Sin 35:941-946

20. Nishida Y, Suzuki K, Kumagai Y, Tanaka H, Inoue A, Ojima T (2007) Isolation and primary structure of a cellulase from the Japanese sea urchin Strongylocentrotus nudus. Biochimie 89:1002-1011

21. Kelly MS (2004) Echinoderms. In: Heinzeller T, Nebeisick JH (eds) Munchen. Taylor and Francis, London, pp 283-289 
22. Lawrence JM (2007) Biology and ecology. In: Lawrence JM (ed) Edible sea urchins. Elsevier Science, Amsterdam, pp 1-9

23. Hultin E, Wanntorp I (1966) Viscosimetric determination of cellulase activity in the intestine of the sea urchin: reaction mechanism and equilibrium constant for cellulase stabilization with calcium. Acta Chem Scand 20:2667-2677

24. Elyakova LA (1972) Distribution of cellulases and chitinases in marine invertebrates. Comp Biochem Physiol 43B:67-70

25. Elyakova LA, Shevchenko NM, Avaeva SM (1981) A comparative study of carbohydrase activities in marine invertebrates. Comp Biochem Physiol 69B:905-908

26. Suzuki M, Nikuchi R, Onishi T (1984) The polysaccharide degradation activity in digestive tract of sea urchin Strongylocentrotus nudus. Bull Jpn Soc Sci Fish 50:1255-1260

27. Yamaguchi K, Araki I, Aoki T, Tseng C-H, Kitamikodo M (1989) Algal cell wall-degrading enzymes from viscera of marine animals. Nippon Suisan Gakkaishi 55:105-110

28. Obrietan K, Drinkwine M, Williams DC (1991) Amylase, cellulase and protease activities in surface and gut tissues of Dendraster excentricus, Pisaster ochraceus and Strongylocentrotus droebachiensis (Echinodermata). Mar Biol 109:53-57

29. Gomez-Pinchetti JL, Garcia-Reina G (1993) Enzymes from marine phycophages that degrade cell walls of seaweeds. Mar Biol 116:553-558

30. Park J, Johnson MJ (1949) A submicrodetermination of glucose. Biol Chem 181:149-151

31. Laemmli UK (1970) Cleavage of structural proteins during the assembly of the head of bacteriophage T4. Nature 227:680-685

32. Beguin P (1983) Detection of cellulase activity in polyacrylamide gels using Congo red-stained agar replicas. Anal Biochem 131:333-336

33. Gornall AG, Bardawill CJ, David MM (1949) Determination of serum proteins by means of the biuret reaction. J Biol Chem 177:751-766

34. Lowry OH, Rosebrough NJ, Farr AL, Randall RJ (1951) Protein measurement with the Folin phenol reagent. J Biol Chem 193:265-275

35. Zhu XD, Mahairas G, Illies M, Cameron RA, Davidson EH, Ettensohn CA (2001) A large-scale analysis of mRNA expressed by primary mesenchyme cells of the sea urchin embryo. Development 128:2615-2627

36. Dehal P, Satou Y, Campbell RK, Chapman J, Degnan B et al (2002) The draft genome of Ciona intestinalis: insights into chordate and vertebrate origins. Science 298:2157-2167

37. Chun CZ, Hur SB, Kim YT (1997) Purification and characterization of an endoglucanase from the marine rotifer, Brachionus plicatilis. Mol Biol Int 43:241-249

38. Singht J, Batra N, Sobti RC (2004) Purification and characterization of alkaline cellulase produced by a novel isolate, Bacillus sphaericus JS1. J Microbiol Biotechnol 31:51-56

39. Mawadza C, Hatti-Kaul R, Zvauya R, Mattiasson B (2000) Purification and characterization of cellulase produced by two Bacillus strains. J Biotechnol 83:177-187

40. Molodtsov NV, Vafina MG (1972) The distribution of $\beta-N$ acetylglucosaminidase in marine invertebrates. Comp Biochem Physiol 41B:113-120
41. Molodtsov NV, Vafina MG, Kim A, Sundukova EV, Artyukov AA, Bliknov YG (1974) Glycosidases of marine invertebrates from Poset Bay, Sea of Japan. Comp Biochem Physiol 48B:463-470

42. Klinger TS (1984) Activities and kinetics of digestive $\alpha$ - and $\beta$ glucosidase and $\beta$-galactosidase of five species of echinoids (Echinodermata). Comp Biochem Physiol 78A:597-600

43. Holzman TF, Russo SF, Williams DC (1985) Effects of feeding and starvation on proteolytic and tryptic activities in pyloric caecal tissues and duct fluids of the sea star Pisaster ochraceus. Mar Biol 90:55-59

44. Farrand AL, Williams DC (1988) Isolation, purification and partial characterization of four digestive proteases from the purple seastar Pisaster ochraceus. Mar Biol 97:231-236

45. Nakatani N, Kobayashi I (1996) Enzymatic properties of a-amylase from sea urchin, Strongylocantrotus nudus. Comp Biochem Physiol 113B:383-386

46. Klinger TS, Hsierh HL, Pangallo RA, Chen CP, Lawrence JM (1986) The effect of temperature on feeding, digestion, and absorption of Lyechinus variegates (Lamarck) (Echinodermata: Echinoidea). Physiol Zool 59:332-336

47. Ura K, Tanaka E, Todo T, Gotoh T, Shimizu M, Ojima T, Takagi Y (2009) Purification of subtilase from short-spined sea urchin Strongylocentrotus intermedius. Bull Fish Sci Hokkaido Univ 58:21-28

48. Chang Y-Q, Lawrence JM, Cao X-B, Lawrence AL (2005) Food consumption, absorption, assimilation and growth of the sea urchin Strongylocentrotus intermedius fed a prepared food and the alga Laminaria japonica. J World Aquac Soc 36:68-75

49. Fuji A (1962) Studies on the biology of the sea urchin, V. Food consumption of Strogylocentrotus intermedius. Jpn J Ecol 12:181-186

50. Fuji A (1967) Ecological studies on the growth and food consumption of Japanese common littoral sea urchin, Strogylocentrotus intermedius (A.Agassiz). Mem Fac Fish Hokkaido Univ 12:83-160

51. Miller RJ, Mann KH (1973) Ecological energetics of the seaweed zone in marine bay on the Atlantic coast of Canada. III. Energy transformations by sea urchins. Mar Biol 18:99-114

52. Larson BR, Vadas RL, Keser M (1980) Feeding and nutritional ecology of the sea urchin Strongylocentrotus droebachiensis in Maine USA. Mar Biol 59:49-62

53. Pearce CM, Williams SW, Yuan F, Castell JD, Robinson SMC (2005) Effect of temperature on somatic growth and survivorship of early post-settled green sea urchin, Strongylocentrotus droebachiensis (Muller). Aquac Res 36:600-609

54. Agatsuma Y (2007) Ecology of Strogylocentrotus nudus. In: Lawrence JM (ed) Edible sea urchins. Elsevier Science, Amsterdam, pp 443-457

55. Stott FC (1995) The food canal of the sea-urchin Echinus esculentus L. and its functions. Proc Zool Soc Lond 125:63-86

56. Ura K, Hasegawa S, Tanaka E, Gotoh T, Ojima T, Takagi Y (2012) Immunohistochemical analysis of the proteolytic enzyme subtilase in the digestive organs of the sea urchin Strongylocentrotus intermedius. Anat Rec 295:73-77 